CZASOPISMO INŻYNIERII LA¿DOWEJ, ŚRODOWISKA I ARCHITEKTURY JOURNAL OF CIVIL ENGINEERING, ENVIRONMENT AND ARCHITECTURE JCEEA, t. XXXIII, z. 63 (2/I/16), kwiecień-czerwiec 2016, s. 337-347

Marek URBANIK ${ }^{1}$

\title{
CONSEQUENCES OF FAILURE OF GAS NETWORK INFRASTRUCTURE
}

\begin{abstract}
Ecology today is becoming increasingly important. Increasing air pollution and greenhouse gas emissions make the search for such fuels which will not have such a negative effect on the environment as the fuel use currently - mainly coal. At present it seems that the substitute fuel can be gaseous fuels (propane-butane, methane). Their combustion is less harmful to the environment and their transport is relatively not very complicated. As it turns out, the use of gas is increasing in industry, automotive, heating systems (power plants that operate in the so-called cogeneration). The increase in demand carries continuous development of gas infrastructure, which in turn may increase probability of failure. As a conclusion of this article, taking into account all the construction disasters induced by the gas, the number of such failures is relatively small. It should be remembered, that the disaster caused by gas explosion may cause very large material and human losses. Not without significance is the impact of gas leakage, eg. of the pipeline on the environment. An example is the methane which is a greenhouse gas, less persistent in the air, but much more active than $\mathrm{CO}_{2}$. The article presents selected disasters associated with natural gas or propane-butane and the impact of these gases on the environment because these fuels are most commonly used in most sectors of the economy.
\end{abstract}

Keywords: natural gas, gas explosion, gas combustion, the failure of the gas network

\section{Introduction}

Currently, natural gas is a source of energy, which is used more intensively. This fuel is increasingly used in many areas of the economy, e.g. automotive, energy, households. Therefore the need for a power source is growing and, in turn, it causes the necessity to expand the network of gas pipelines.

Another factor determining the increased interest in fuel gas is ecology. The increasing pollution and greenhouse effect deepening stimulates the slow but systematic shift away from petroleum based on fuels and coal. In comparison with these fuels, gas seems to be a good alternative. Combustion gas is practical-

\footnotetext{
${ }^{1}$ Autor do korespondencji/corresponding author: Marek Urbanik, Politechnika Rzeszowska, al. Powstańców Warszawy 6, 35-959 Rzeszów, tel. 17 8651408, marekurbanik@vp.pl
} 
ly without solid particles and less harmful compounds. On the other hand failures of gas distribution system can cause damage of property and loss of life. Leaking gas negatively affects the local environment and the long uncontrolled leakage of gas appear over large areas [3]. The current trend is observed in the gas supply is steady decline in incidents involving deaths and injuries in the last twenty years $[10,12]$. But still large part of the network was built almost seventy years ago, such situation can cause numerous accidents, as gas explosion or result in human losses or injuries [11]. As to decrease the number of failure many action and programme where implemented, but still there is great urgency of continuous efforts in this field.

Increasing length of gas pipelines increases the probability of their failure. In turn, the gas pipeline failure generally causes more or less of gas leakage, which results in various consequences - as described in this work.

\section{The consequences of the gas leak}

The consequences of gas leakage depends mainly on the place of leakage (open or closed space) and the amount of "escaping" gas per unit time. Also it is not without significance the size of the mouth (the gap) through which the gas escapes. One of the most common consequences of an uncontrolled leakage of gas is its ignition and then explosion, but certain conditions must be met before it happens. The main factor necessary for the occurrence of escaping gas ignition is its concentration, which in case of methane ranges from $4.9 \%$ to $15.4 \%$ [13]. The outbreak of the greatest strength occurs when the concentration of methane is approx. 9\% [5, 14]. Above or below the level of the explosive force decreases, since the smaller the gas concentration, it simply not enough to cause the gas ignition and when more gas is explosive force is reduced by small amount of oxygen, which is necessary to ignite the gas. Second factor after the gas concentration is the source of ignition. In this case the autoignition temperature is important, which for the methane is $535^{\circ} \mathrm{C}$ [13]. If we heat the gas to this temperature, it will ignite without a direct source of fire. In case of pipelines such temperature practically does not occur. Gas escaping from a leaky pipeline ignites mainly from the source of fire begining from sparks (e.g. a spark in electrical devices or a spark caused by hitting of metal on metal) and ending with the open source of fire or flame.

The combustion of natural gas as other gases may occur in a controlled and uncontrolled way:

- controlled combustion (i.e. diffusional) involves diffusion of the oxidant gas,

- uncontrolled combustion (i.e. kinetic) depends on the rate of reaction of the oxidant and the combustible body, the faster the reaction the more violent combustion.

Of course, the combustion kinetics is associated with a greater loss [13]. The consequences of a gas explosion may be different, they depend on the com- 
bustion type (kinetic or diffusional) and on the environment in which the leak occurred.

The process of creation of the gas explosion is illustrated in the Figure 1.

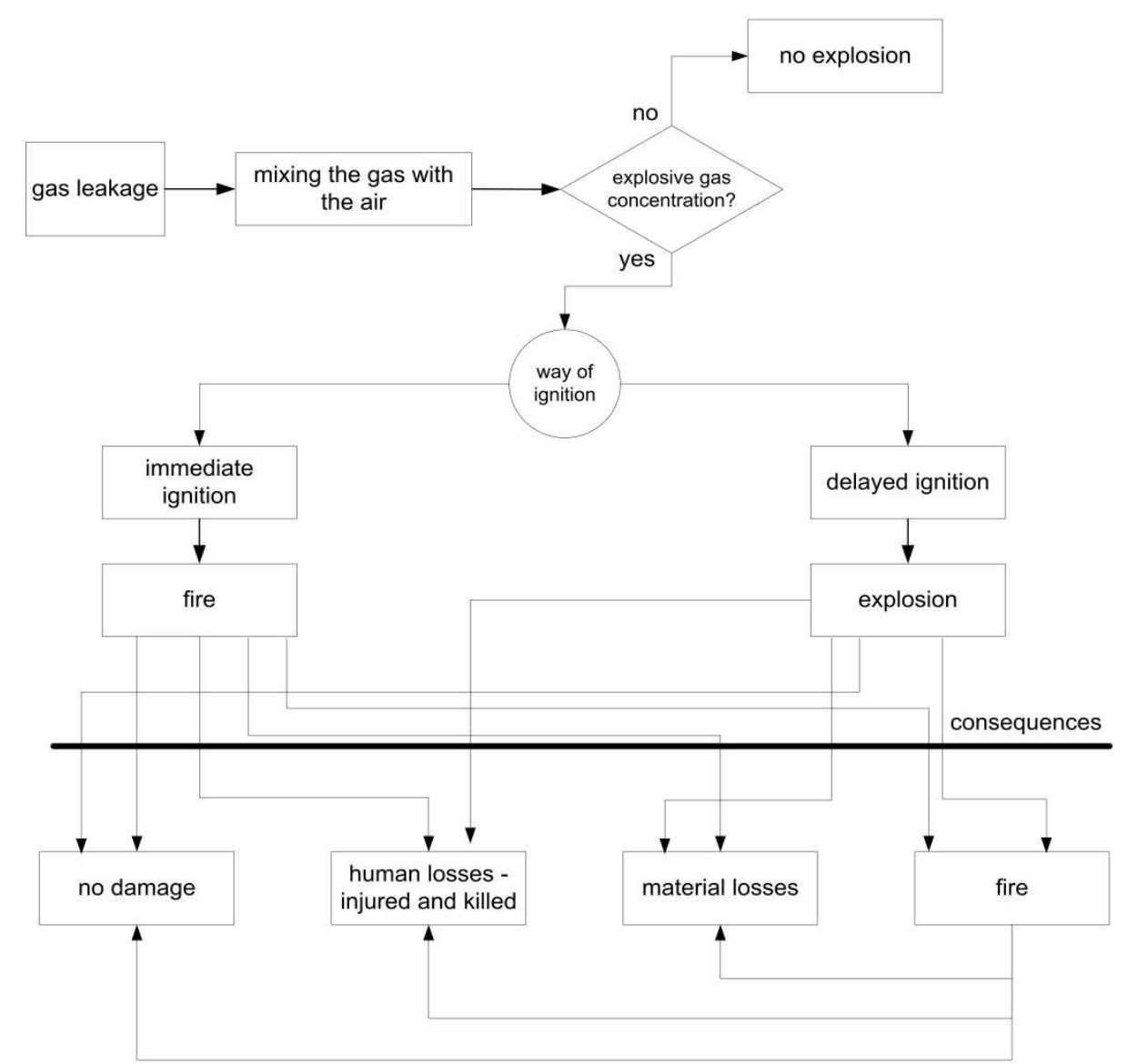

Fig. 1. Gas explosion and its consequences, on the basis of $[1,2]$

Rys. 1. Wybuchu gazu wraz z jego konsekwencjami, opracowano na podstawie $[1,2]$

The consequences of ignition of gas escaping from the pipeline depend on whether there was an explosion or flame combustion. The explosion occurs when in a specific area gas with a specific concentration gathers (approx. 9\%), which will result in the rapid ignition and burning. A sudden rise in temperature and pressure cause the displacement of large air masses outside the explosion site. The air moving at high speed forms the so-called shock wave. The spread speed of the explosion after the ignition of natural gas is approx. $2320 \mathrm{~m} / \mathrm{s}$. Due to the high speed of the shock wave, it causes a significant loss of material and creates great danger for the lives of people located within its activity. Gas 
explosions occur mostly when gas flows into enclosed spaces, where it quickly reaches explosive levels. Although pipelines with medium and low pressure do not pass directly through the buildings, it happens that escaping gas is one of causes of explosion in the buildings where sometimes there is no gas installation. Scheme of such activity is following: through damaged pipeline gas penetrates into the surrounding of gas pipe. Often (especially in large urban areas) next to the gas pipelines are sewer lines, water supply systems, electrical and ICT systems. Gas escapes from the pipeline in the simplest way and goes to the channels, which are pipes of above mentioned infrastructure delivering media to the buildings. From these channels gas usually goes to the cellars of buildings, where its concentration slowly but steadily increases. It should be remembered that the amount of gas flowing into the building in time unit depends on the speed of a gas leak, distance from pipeline to the building and from the way which gas enters building (cross section of channels and their number). Potentially, from the damaged pipeline more gas may enter the building in the winter because in the frozen ground there are slots through which gas slowly but regularly flows into the building. The cellars are relatively infrequently used rooms so the incoming gas is not immediately identified. In addition, vigilance is reduced in buildings where the gas is not restored. When the gas concentration reaches an appropriate level, just a minor source of ignition can cause the explosion (eg. a spark in the light switch) [9].

Examples of selected disasters associated with the explosion of gas in buildings to which gas got from the depressurized pipeline:

- February 1, 1976 - Gdańsk Siedlce, a gas explosion in a two-storey building, which had no gas installation. The cause of the explosion was that gas got through leaky pipeline from other building. The source of ignition was the inclusion of lighting in the basement of one resident. As a result of the incident 17 people were killed and 11 injured [15],

- February 22, 1982 - Łódź, a gas explosion in one storey building, which destroyed the entire ground floor, saving load-bearing walls. The cause of failure was the passage of gas from a corroded pipeline, which was located outside the building. Gas got into the basement through the heat pipe. The incident killed two people, while 10 were injured [15],

- Russia (near the Urals), a gas leak from a damaged pipeline, which was located next to the railway line. Gas escaping from a pipeline for a long time contributed to the creation of the zones next to the track where the gas concentration reached the explosive value. The explosion happened when two trains (carrying approx. 1200 passengers) passed near the damaged pipeline. The cause of the explosion were sparks coming from under the wheels of trains. The crash killed approx. 645 people and twice as many were injured. The cause of a leakage was damage of the gas pipeline made by the excavator in 1985. Over the years a leak in the pipeline became bigger and led to a substantial gas leak causing explosion [4], 
- February 15, 1979 - Warsaw, one of the biggest disasters in Poland triggered by the explosion of natural gas, the explosion happened in the Rotunda PKO. It is worth to mention that the building of the Rotunda was not connected to the gas network. The reason for getting the gas to the building and consequently the explosion was unsealing the underground pipeline that runs near the Rotunda from which the gas got into the building through telecommunication channels and there after reaching the explosive concentration exploded. The incident killed 49 people, while 135 were injured. The building was destroyed in $70 \%$ [6].

From the above examples, it can be seen that the depressurized pipeline could cause a gas explosion inside the building. As indicated earlier, gas under certain conditions, may cause explosion or burn with flame. The burning flame of gas does not occur as rapidly as an explosion, causing some minor effects but also severe. Gas flame burns when the environment to which gas escapes does not allow to achieve concentrations of explosive, it usually happens in open spaces. During flame burning a shock wave does not occur, but is accompanied by a phenomenon also dangerous. The point is that the gas coming out of the technical equipment, e.g. gas pipeline tends to move to relatively long distances in the form of cloud.

When such a "migrating" cloud of gas encounters the source of fire, e.g. a spark from the chimney, it starts to burn. In this way a fire caused by a gas leak may spread long distances and cover large areas that are difficult to control. An example of such a disaster associated with the gas flame burning can be a fire that took place on 14 November 2013 in Jankowo Przygodzki. According to the source [15] the cause of the explosion was faults made during the construction of a new gas pipeline next to the existing one. According to the experts during the construction of the new pipeline the excavated earth was improperly stored. The excavated earth was stored too close to the "old" gas pipeline, also heaped escarpment was too high, resulting that the pipeline slipped into the pit prepared for the new pipeline. Landslide caused unsealing the pipeline. The second fault, which led to a leakage of the gas pipeline was a defective weld made at joining two parts of the pipeline [15]. As a result, the large amount of gas leaked into the atmosphere, which at first exploded and then started a fire. Some sources say that the spread of fire was caused by a gas cloud which moved from the site of leakage to the buildings. After reaching a sufficient concentration a cloud was ignited by, for example, a spark from the chimney and caused a fire [8]. The fire destroyed 10 houses and 2 outbuildings, 2 people were killed (men working on the construction of a new gas pipeline), while 13 people were injured.

How destructive force can be gas explosion shows an example of catastrophe, that occurred in San Juanico on 19 November 1984. In this case, the type of gas which exploded was LPG, a mixture of propane (80\%) and butane (20\%). According to experts, the investigation established a probable disaster scenario, the crash was initiated by a rupture of pipeline by which LPG flew. 
Due to the fact that the gas is heavier than air, the "cloud" of gas began to spin on the ground and then was ignited by flare in the form of the so called candle firing the gas excess. The burning warmed the gas tanks of LPG, which under the influence of high temperature were damaged. 15 out of 48 tanks were destroyed, their weight was 20 tons. Those tanks as a result of the explosion were transferred to the distance from 100 to 1000 meters, which contributed to the damage outside the plant.

The four spherical tanks with a capacity of $1500 \mathrm{~m}^{3}$ (containing LPG in the liquid state) as a result of the explosion turned into fireballs with a diameter of 200-300 meters, which burned for approx. 20 seconds. Burning drops of liquid gas from the burning tanks moved for long distances, thus creating a fiery rain. The force of the blast, created as a result of temperature increase, caused that from the burning tanks besides burning gas also the fragments of tanks, weighing from 10 to 40 tones, were thrown out and have been found even at a distance of approx. 900 meters from the blast site. The explosion killed 550 people and injured more than 2000. This catastrophe is now considered as one of the biggest and most tragic disasters caused by gas explosion [4].

\section{Environmental pollution}

Leaking gas from depressurized pipeline or other device for gas transport or storing not only causes an explosion and fire but also environmental pollution or ecological disasters. Natural gas contains almost $98 \%$ of methane, which is a greenhouse gas approx. 23 times more effective than $\mathrm{CO}_{2}$.

However, it should be noted, that the impact of methane (which leaked from the pipeline) on the greenhouse effect is negligible, the reason for this is relative small amounts of methane in the air.

On the other side, escaping natural gas in considerable amounts can cause serious pollution of the local environment. Excessive amounts of methane in the air can cause nausea, headache or respiratory irritation. By displacing oxygen from the air by methane, the excessive concentration of the gas can lead to suffocation.

An example of an environmental disaster associated with natural gas is uncontrolled gas leak which took place at the end of 2015 in California. In this case, the gas leaked from a bed in Porter Ranch. Within one day, into the atmosphere got nearly two million cubic meters of methane. Elevated concentrations of methane in the air has caused the deterioration of the health of the local population. People complained about headaches, dizziness and problems with the respiratory system. As a result of leakage of such a large amount of gas the local authorities declared a state of emergency and the evacuation of the population. Escaping gas also had a devastating impact on the environment. 
As estimated by experts, escaping methane only in one day caused such negative effects as emission of approx. 7 million cars [7]. It is worth to mention about the consequences of the gas leak from a gas pipeline located under water.

Unfortunately, the current state of the consequences of the impact of methane on the underwater world is not fully known. However, it was found that natural gas in excessive concentration in water is toxic for living organisms. The large fish sensitivity to methane is observed, the gas paralyses their nervous system. In places where gas leakage occurs, the extinction of aquatic organisms is observed.

\section{Disasters caused by gas explosion in numbers}

Building catastrophe is not intentional, violent destruction of the object or its part [16]. The statistics of construction disasters in different years was developed on the base of the literature $[15,17]$.

In the years 2004-2014 the most construction disasters caused by gas explosion occurred in 2008 (of about 1113 disaster), while the smallest number of disasters were recorded in 2005 - only 132 (Figure 2).

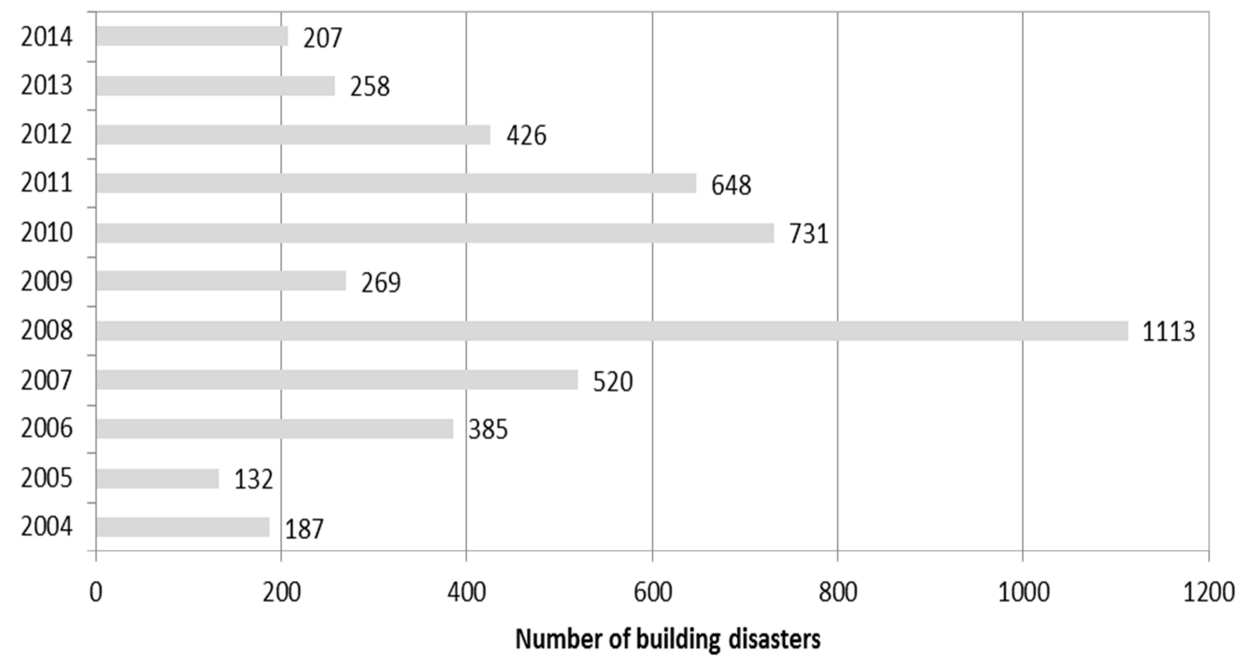

Fig. 2. The total number of building disasters in the years 2004-2014, developed on the basis of $[15,17]$

Rys. 2. Liczba wszystkich katastrof budowlanych spowodowane wybuchem gazu w latach 20042014, opracowano na podstawie [15, 17]

In case of the construction disasters caused by gas the highest number was recorded in 2013 - 30, while the smallest number of catastrophes involving gas was in 2004, only 8 (Figure 3 ). 


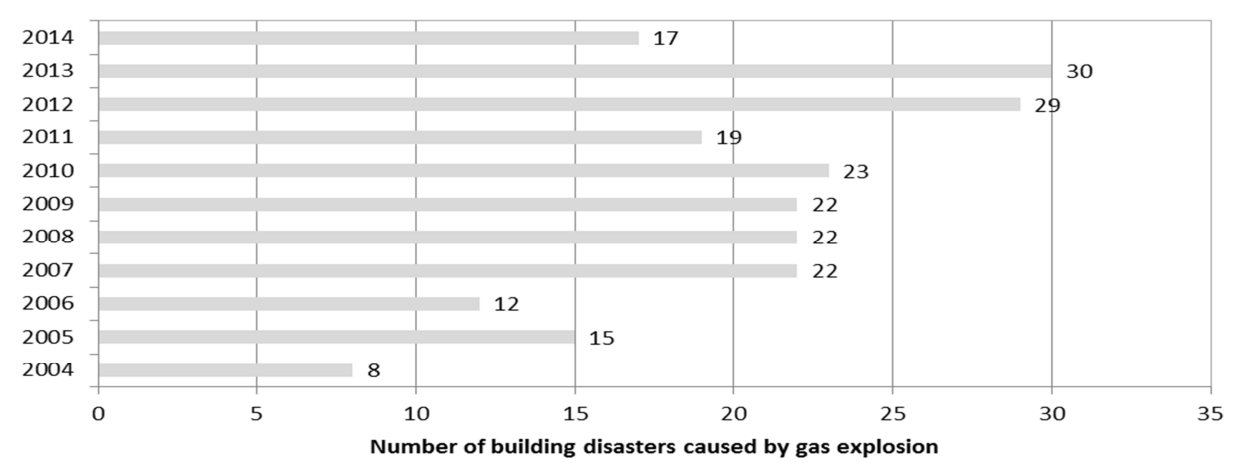

Fig. 3. The total number of building disasters caused by gas explosion in the years 2004-2014, developed on the basis of $[15,17]$

Rys. 3. Liczba wszystkich katastrof budowlanych spowodowanych wybuchem gazu w latach 2004-2014, opracowano na podstawie [15, 17]

Taking into account the gas as a factor causing the disaster construction the gas type should be taken into account (Figure 4). Considering only the construction disasters in which the gas was the cause of the disaster it clearly states that natural gas caused less disasters than in the case of propane-butane. The explosion of propane-butane caused many catastrophes in 2012 up to 22, while natural gas caused the most catastrophes in 2013, only 13.

Almost every catastrophe is associated with injures or the death of people. The comparison between the number of people who lost their lives or were injured in all the catastrophes and in the catastrophes caused by gas is shown in Figures 5-6.

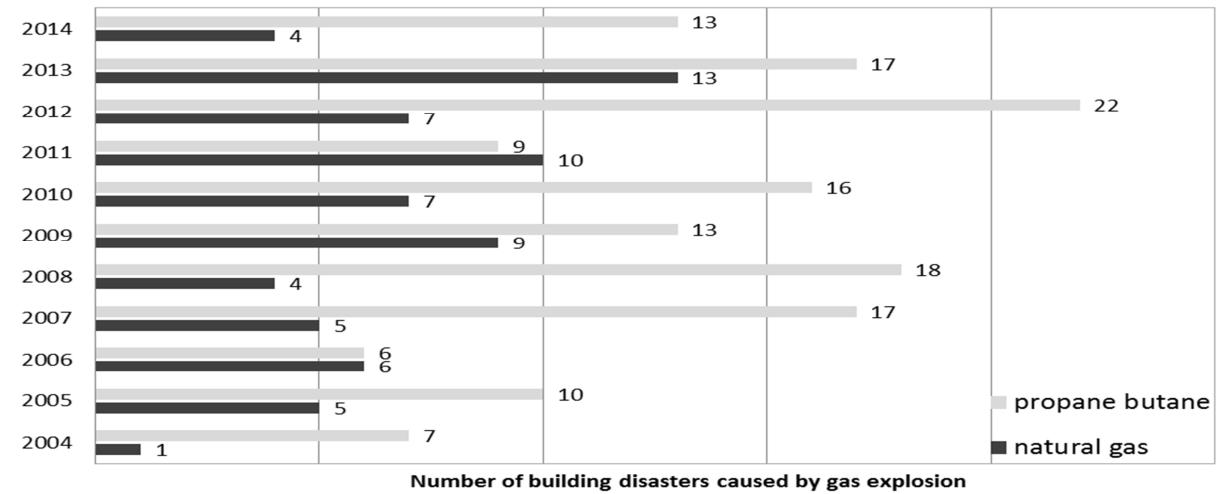

Fig. 4. The total number of building disasters caused by gas explosion with division into natural gas and propane-butane in the years 2004-2014, developed on the basis of [15, 17]

Rys. 4. Liczba wszystkich katastrof budowlanych spowodowanych wybuchem gazu z podziałem na gaz ziemny i propan-butan w latach 2004-2014, opracowano na podstawie [15, 17] 


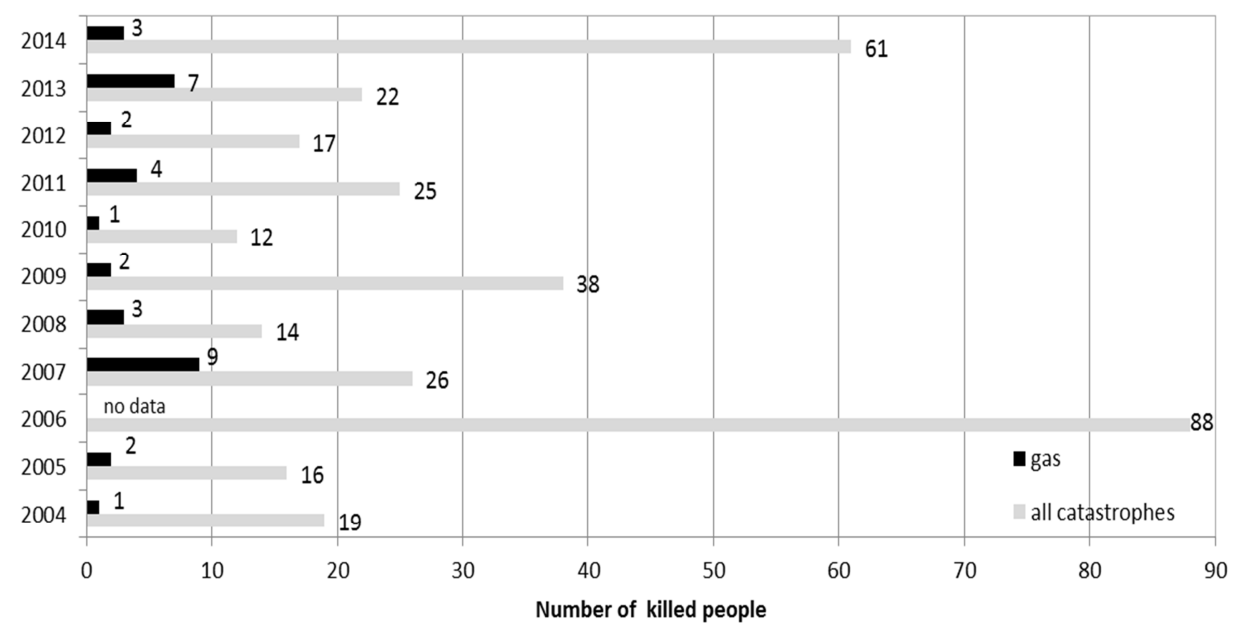

Fig. 5. The number of people killed in all the catastrophes and in the catastrophes caused by gas in the years 2004-2014, developed on the basis of [15, 17]

Rys. 5. Liczba osób zabitych we wszystkich katastrofach i tych wywołanych gazem w latach 2004-2014, opracowano na podstawie [15, 17]

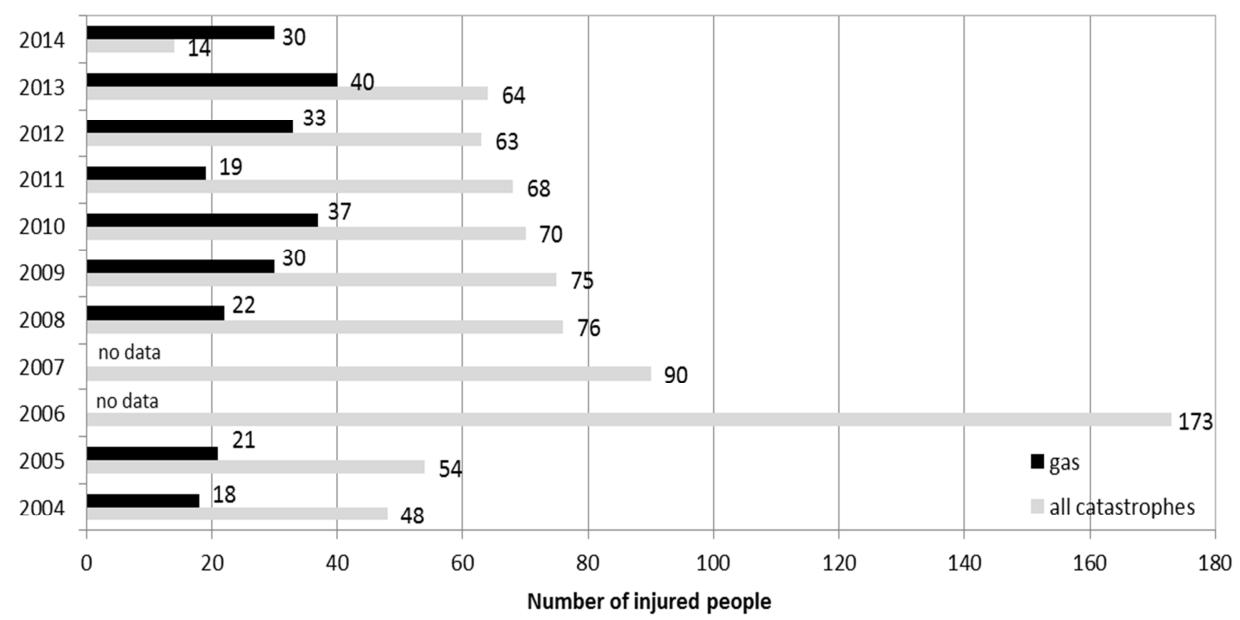

Fig. 6. The number of people injured in all catastrophes and in the catastrophes caused by gas in the years 2004-2014, developed on the basis of [15, 17]

Rys. 6. Liczba osób rannych we wszystkich katastrofach i tych wywołanych gazem w latach 2004-2014, opracowano na podstawie [15, 17]

Analysing Figures 5 and 6 it can easily be seen that the number of people injured in the catastrophes caused by gas is relatively small compared with other catastrophes. However, the catastrophes related to gas are more spectacular and more frequently publicized by the media than the others. 


\section{Conclusion}

In general, disasters, also those associated with gas, are caused by not one but several consecutive events. The gas failure can be caused by fault at design or installation, which connected with the improper use can lead to a gas leak. Occasionally, it happens that uncontrolled gas leak is caused intentionally by humans, e.g. by suicide or gas theft. The above analysis shows that much less construction disasters are caused by natural gas than by liquid gas (propanebutane). It may be related to the properties of gas. Natural gas is lighter than air and in the case of leakage rises upwards and enters the ventilation systems. It should also be remembered that the methane gas to households is delivered through a network of pipelines. In the case of propane-butane gas is heavier than air and ventilation system instead gathers on the substrate. Propane-butane in contrast to methane into the household is supplied in cylinders. These cylinders often are connected by people not having proper qualifications and hence more disasters are caused by this type of gas. In order to minimize the failure probability of gas distribution system various activities should be taken. These activities can be divided into active, that are intended to prevent crashes (or reduce the risk of their occurrence) and passive, which task is to minimize the failure consequences when it happens. Another example of safety measures, which should be used as to protect before the failure is the use of new materials to build devices of gas distribution system and better protection them against corrosion. Therefore as to protect and minimize the consequences of failure of gas network infrastructure active development of new procedures from the design stage through to gas infrastructure operation should be implemented.

\section{Literature}

[1] Bjerketvedt D., Bakke J.R., Wingerden K.: Gas explosion handbook, ver. 1.2, Bergen, 1993.

[2] Chyży T.: Wybuch gazu w budynkach mieszkalnych. Wybuch wentylowany - Biuletyn WAT, vol. LXIII , Nr 3/2014, s. 159-173.

[3] Hasan F., Iqbal J.: Consequential rupture of gas pipeline, Engineering Failure Analysis, Vol. 13, 2006, pp. 127-135.

[4] http://archiwum.ciop.pl/18388.html - Serwis nt. przeciwdziałania poważnym awariom przemysłowym [dostęp 10.01 .2016 r.].

[5] http://cza.republika.pl/zagrozenie\%20metanowe.htm [dostęp 10.01.2016 r.].

[6] http://www.polskieradio.pl/39/156/Artykul/782575,Wybuch-w-Rotundzie-PKO-naj wieksza-katastrofa-w-powojennej-historii-Warszawy [dostęp 10.01.2016 r.].

[7] http://www.tvp.info/23494104/katastrofa-ekologiczna-w-kalifornii-wyciek-metanuporownywalny-z-emisja-spalin-kilku-milionow-samochodow - Reuters, IAR, TVP Info, Los Angeles Daily News [dostęp 15.01.2016 r.].

[8] http://wyborcza.pl/1,76842,14962145,Dlaczego_w_Janikowie_wybuchl_gaz_To_ni e_byl_pierwszy.html - Dlaczego w Janikowie wybuchł gaz? To nie był pierwszy taki wypadek - Glubiak G., Żytnicki P., Lehman A. [dostęp 10.01.2016 r.]. 
[9] Majid Z.A., Mohsin R., Yaacob Z., Hassan Z.: Failure analysis of natural gas pipes, Engineering Failure Analysis, Vol. 17, 4/2010, pp. 818-837. DOI: 10.1016/j.engfailanal.2009.10.016.

[10] Mannan S.: Lees' Loss Prevention in the Process Industries, Hazard Identification, Assessment and Control, Third Edition, Elsevier Butterworth-Heinemann, Burlingtion 2005.

[11] Montiel H., Vilchez J.A., Arnaldos J., Casal J.: Historical analysis of accidents in the transportation of natural gas, Journal of Hazardous Materials, Vol. 51, 1-3/1996, pp. 77-92. DOI: 10.1016/S0304-3894(96)01819-5.

[12] Ramirez-Camacho J.G., Pastor E., Casal J., Amaya-Gomez R., Munoz-Giraldo F.: Analysis of domino effect in pipelines, Journal of Hazardous Materials, Vol. 298, 2015, pp. 210-220. DOI: 10.1016/j.jhazmat.2015.05.033.

[13] Sawicki T.: Wybuchy przestrzenne, Bezpieczeństwo pracy, Nr 11/2005, s. 22-25.

[14] Shalaby H.M., Riad W.T., Alhazza A.A., Behbehani M.H.: Failure analysis of fuel supply pipeline, Engineering Failure Analysis, Vol. 13, 5/2006, pp. 789-796. DOI: 10.1016/j.engfailanal.2005.02.004.

[15] Szer J.: Katastrofy budowlane spowodowane wybuchem gazu - XXVII Konferencja Naukowo-Techniczna-Awarie Budowlane 2015, s. 121-130.

[16] Ustawa z dnia 7 lipca 1994 r. - Prawo budowlane art. 73 ust.1 (Dz.U. 1994 nr 89, poz. 414).

[17] www.gunb.gov.pl [dostęp 8.01.2016 r.].

\section{SKUTKI AWARII INFRASTRUKTURY GAZOWEJ}

\section{Streszczenie}

Ekologia w dzisiejszych czasach nabiera coraz większego znaczenia. Rosnące zanieczyszczenie powietrza i emisja gazów cieplarnianych zmusza do poszukiwań takich paliw , które nie będą miały tak negatywnego skutku na środowisko jak paliwa obecnie stosowane - głównie węgiel i paliwa ropopochodne. Obecny trend pokazuje, że paliwem zastępczym mogą być paliwa gazowe (propanbutan, metan). W wyniku spalania emitują mniej szkodliwych związków do środowiska a ich transport nie jest stosunkowo zbyt skomplikowany. Jak się okazuje, paliwa gazowe zajmują coraz większe zastosowanie w przemyśle, motoryzacji, ogrzewnictwie (elektrociepłownie, które pracują w tzw. kogeneracji). Wzrost zapotrzebowania niesie za sobą ciągły rozwój infrastruktury gazowej, co z kolei może zwiększyć prawdopodobieństwo awarii. Jak wynika z niniejszego artykułu, biorąc pod uwagę wszystkie katastrofy budowlane udział tych wywołanych gazem jest stosunkowo mały. Należy jednak pamiętać, że katastrofa spowodowana wybuchem gazu może nieść za sobą bardzo duże straty materialne i ludzkie. Nie bez znaczenia jest wpływ wyciekającego gazu np. z gazociągu na środowisko. Przykładem jest metan, który jest gazem cieplarnianym, co prawda krócej utrzymującym się w powietrzu ale dużo bardziej aktywnym niż $\mathrm{CO}_{2}$. W artykule przedstawiono wybrane katastrofy związane z gazem ziemnym lub propanem-butanem oraz wpływ tych gazów na środowisko, ponieważ paliwa te są najczęściej stosowane w większości dziedzin gospodarki.

Słowa kluczowe: gaz ziemny, wybuch gazu, spalanie gazu, awaria sieci gazowej

Przestano do redakcji: 29.11.2015 r.

Przyjęto do druku: 1.06.2016 r.

DOI: $10.7862 / \mathrm{rb} .2016 .135$ 
